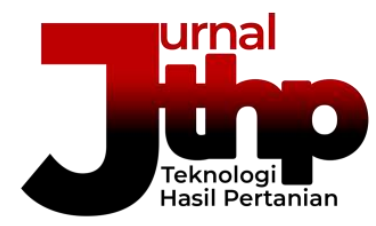

Jurnal Teknologi Hasil Pertanian. 13(2), 111-123

URL: https://jurnal.uns.ac.id/ilmupangan/article/view/43120

DOi: https://doi.org/10.20961/jthp.v13i2.43120

ISSN 1979-0309 (Online) 2614-7920 (Print)

\title{
UMUR SIMPAN SAMBAL PARI (Dasyatis Sp.) ASAP YANG DIKEMAS JAR PADA BEBERAPA CARA PEMASAKAN DENGAN METODE PENDUGAAN ACCELERATED SHELF-LIFE TESTING (ASLT)
}

\author{
USING ACCELERATED SHELF-LIFE TESTING (ASLT) TO ESTIMATE THE SHELF-LIFE \\ OF SMOKED-STINGRAYS CHILLI SAUCES (Dasyatis Sp.) IN A JAR PACKAGE AND \\ COOKED UNDER VARIOUS CONDITION
}

\author{
Dian Rachmawanti Affandi ${ }^{1}$, Adhitya Pitara Sanjaya ${ }^{2}$, dan Santi Rahma Mardiana ${ }^{2}$ \\ ${ }^{1}$ Department of Agricultural Product Technology, Universitas Sebelas Maret \\ ${ }^{2}$ Department of Food Science and Technology, Faculty of Agriculture, Universitas Sebelas Maret \\ Email: d_affa@hotmail.com
}

Diserahkan [20 Juli 2020]; Diterima [18 Agustus 2020]; Dipublikasi [22 Agustus 2020]

\begin{abstract}
The addition of smoked stingrays in chili sauces would be an alternative way to utilize the smoked stingrays. Meanwhile, adding it into a chili sauce will lead to a distinctive taste. During the storage time, the chili sauce undergoes a decrease in microbiological quality and causes changes in aroma and the emergence of acid in the sauce, hence the product would be rejected by consumers. This study aims to determine the best cooking method to produce smoked stingray chili sauces with best sensory, chemical, and microbiological quality as well as to extend its shelf life. Packaging using glass jars and a variety of cooking methods for smoked stingray sauce have been done to prevent quality degradation. The variations in the cooking methods were dry cooking (P1), semi-dry cooking (P2), and dry cooking with the addition of oil after cooking (P3). Furthermore, to meet food safety standards and quality assurance as well, an estimation of the shelf life of the smoked stingray chili sauces is carried out using the ASLT with Arrhenius model. This method has a relatively short testing time with high accuracy and precision. The parameters tested were aroma sensory, total titrated acid (TAT), and total plate count (TPC). The deterioration in the quality of chili sauces was observed every 12 hours during 48 hours storage time where the storage temperatures are $35^{\circ} \mathrm{C}, 45^{\circ} \mathrm{C}$ and $55^{\circ} \mathrm{C}$. The chili sauce of smoked stingray in glass jar packaging by dry cooking and adding cooking oil has the best aroma quality (close to the aroma of fresh chili sauce) on the same day and temperature during storage, before being rejected. Total titrated acid is also the best (low) compared to chili sauce with dry and semi-dry processing. However, the total plate count (TPC) of smoked stingray chili sauce in glass jar packaging by dry cooking and the addition of cooking oil was relatively no different from other chillies. The best chili sauce is chili sauce with dry cooking and adding cooking oil, with a shelf life of 197.96 hours.
\end{abstract}

Keywords: chilli sauces, smoked stingrays, shelf life, cooking, ASLT

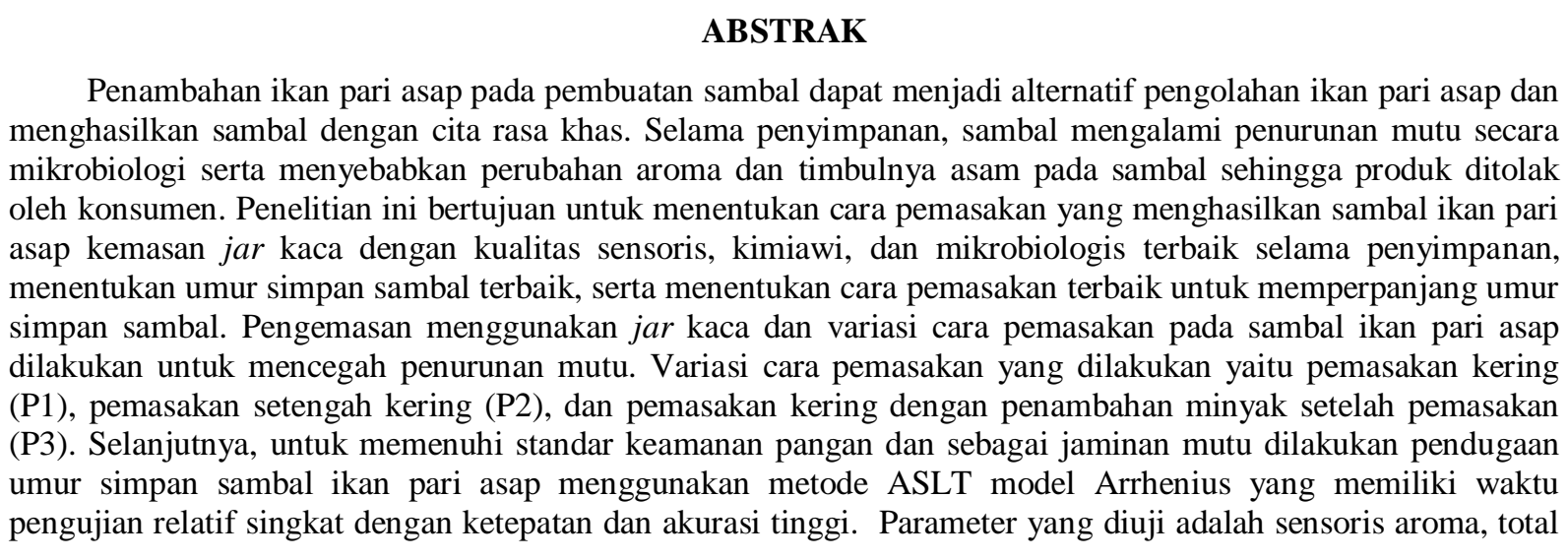


asam tertitrasi (TAT), dan total plate count (TPC). Penurunan mutu sambal diamati pada penyimpanan suhu $35^{\circ} \mathrm{C}, 45^{\circ} \mathrm{C}$ dan $55^{\circ} \mathrm{C}$ selama 48 jam dengan waktu pengamatan setiap 12 jam sekali. Sambal ikan pari asap kemasan jar kaca dengan variasi cara pemasakan kering dengan penambahan minyak goreng kualitas aromanya paling baik (mendekati aroma sambal segar) pada hari dan suhu yang sama selama penyimpanan, sebelum mengalami penolakan. Total asam tertitrasinya juga paling baik (rendah) dibandingkan sambal dengan cara pemsakan kering dan setengah kering. Namun demikian, total plate count (TPC) sambal ikan pari asap kemasan jar kaca dengan variasi cara pemasakan kering dengan penambahan minyak goreng relatif tidak berbeda dengan sambal yang lain. Sambal terbaik adalah sambal dengan pemasakan kering ditambah minyak dengan umur simpan 197,96 jam.

Kata kunci: sambal, ikan pari asap, umur simpan, pemasakan, ASLT

\section{PENDAHULUAN}

Keamanan pangan menjadi sesuatu yang penting dalam penyediaan pangan bagi masyarakat. Keamanan pangan merupakan pra syarat mutlak makanan yang dikonsumsi untuk menjamin bahwa indivisu yang mengkonsumsi tidak terkena foodborne disease. Syarat utama makanan harus aman sebelum mempertimbangkan nilai gizi dan fungsional. Sambal merupakan salah satu produk pangan olahan yang tidak terlepas dari pra sayarat aman.

Sambal berperan penting sebagai penambah atau perangsang selera makan, sehingga beberapa hidangan selalu didampingi dengan sambal yang sesuai untuk memperkaya cita rasa makanan. Dalam Kamus Besar Bahasa Indonesia, sambal didefinisikan sebagai makanan penyedap yang dibuat dari cabai, garam, dan sebagainya yang ditumbuk, dihaluskan, dan sebagainya, biasanya dimakan bersama nasi. Sambal dalam bentuk siap saji yang praktis telah beredar di pasaran Indonesia, diantaranya sambal balado, sambal terasi, sambal kacang, dan sambal goang (Koswara, 2009; Novianti dkk, 2016).

Sambal ikan merupakan salah satu jenis sambal yang digemari pula di Indonesia. Pada penelitian Wahyuningsih dkk (2012), proses pembuatan sambal petis menggunakan ikan tuna, sedangkan pada penelitian Supit dkk (2015), proses pembuatan sambal cahero menggunakan ikan roa sebagai potensi lokal Sulawesi Utara dan menghasilkan sambal dengan cita rasa khas dan gurih. Jenis ikan lainnya yang bisa dipakai sebagai bahan sambal adalah ikan pari yang diasap. Ikan pari asap dapat ditambahkan sebagai bahan sambal untuk menghasilkan cita' rasa dan aroma yang khas.
Selama penyimpanan, produk sambal yang ditambah ikan rentan mengalami penurunan mutu secara mikrobiologi, yang ditandai dengan pertumbuhan mikroba berupa bakteri. Kerusakan sensoris yang terjadi yaitu perubahan aroma atau bau, sedangkan secara kimia adalah timbulnya asam pada sambal. Penurunan mutu pada sambal tersebut menyebabkan penolakan produk oleh konsumen dan penurunan umur simpan sambal, yang terkait dengan tingkat keananan pangan sambal.

Menurut Herawati (2008), upaya memperpanjang umur simpan produk dapat dilakukan dengan memperhatikan tahapan proses produksi. Pada penelitian Dewi dkk (2011), tahapan proses produksi abon ikan nila merah dengan variasi cara pemasakan yang berbeda menghasilkan umur simpan abon yang berbeda. Proses pemasakan abon dengan metode deep frying yang membuat produk kontak dengan lebih banyak minyak goreng membuat abon lebih mudah mengalami oksidasi dibandingkan dengan metode pan frying. Berdasarkan hal tersebut, variasi cara pemasakan yang berbeda pada proses pengolahan sambal ikan pari asap dimungkinkan pula berpengaruh terhadap umur simpan sambal.

Pada pengolahan sambal menurut Koswara (2009), bahan pengemas yang sering digunakan adalah jar kaca. Kelebihan jar kaca yaitu bersifat inert, tahan terhadap tekanan dan nonpermeable (Shin dan Seike, 2014). Pengemasan menggunakan jar kaca pada sambal ikan pari asap dengan variasi cara pemasakan diharapkan dapat memperpanjang umur simpan sambal.

Umur simpan produk sangat penting dicantumkan terkait keamanan dan jaminan mutu produk hingga sampai ke tangan konsumen. Pendugaan umur simpan dengan permodelan matematika yang sering 
digunakan adalah Accelerated Shelf Life Testing (ASLT). Metode ASLT model Arrhenius digunakan untuk menduga umur simpan makanan kaleng steril komersial, susu UHT/bubuk/formula, frozen meat/shrimp/ fish, saus sambal/tomat, bumbu dan kondimen, jem dan produk pangan lain yang mengandung lemak tinggi (berpotensi terjadinya oksidasi lemak) atau mengandung gula pereduksi dan protein (berpotensi terjadi reaksi kecoklatan) (Kusnandar, 2008). Salah satu keuntungan metode Accelerated Shelf Life Testing (ASLT) yaitu waktu pengujian relatif singkat dengan ketepatan dan akurasi tinggi (Arpah dan Syarief, 2000).

Pada penelitian ini akan digunakan tiga variasi cara pemasakan sambal ikan pari asap, yaitu pemasakan kering, pemasakan setengah kering, dan pemasakan kering dengan penambahan minyak goreng setelah pemasakan. Selanjutnya sambal ikan pari asap kemasan jar kaca ditutup rapat dan dilakukan pendugaan umur simpan menggunakan metode Accelerated Shelf-Life Testing (ASLT) dengan model Arrhenius.

Penelitian ini bertujuan untuk menentukan cara pemasakan yang menghasilkan sambal ikan pari asap kemasan jar kaca dengan kualitas sensoris (aroma), kimiawi (total asam tertitrasi), dan mikrobiologis (TPC) terbaik selama penyimpanan, menentukan umur simpan sambal terbaik, serta menentukan cara pemasakan terbaik untuk memperpanjang umur simpan sambal.

\section{METODE PENELITIAN}

\section{Alat}

Alat yang digunakan dalam pembuatan sambal ikan pari asap adalah blender (Miyako), chopper (Miyako), panci, timbangan analitik, kompor (Rinnai RB3SS), dan wajan anti lengket (Emerald Wok). Alat yang digunakan seperangkat alat gelas untuk pengujian total asam tertitrasi (TAT); autoklaf, laminar flow, dan inkubator untuk pengujian total plate count (TPC), serta seperangkat alat untuk uji sensoris.

\section{Bahan}

Bahan yang digunakan untuk sambal adalah ikan pari asap (Dasyatis sp.) diperoleh dari Pasar Ikan Surakarta, bawang merah, bawang putih, cabai merah keriting, cabai rawit, garam (Refina), gula pasir (Gulaku), minyak goreng (Bimoli), dan terasi, sedangkan. Bahan yang digunakan untuk mengemas sambal ikan pari asap berupa jar kaca. Bahan yang digunakan dalam pengujian total asam tertitrasi adalah indikator phenolphthalein (pp), dan $\mathrm{NaOH} 0,1 \mathrm{~N}$, sedangkan pada pengujian total plate count (TPC) diperlukan $\mathrm{NaCl}$ dan plate count agar (OXOID).

\section{Tahapan Penelitian}

\section{Pembuatan sambal}

Proses pembuatan sambal ikan pari asap diawali dengan pengukusan cabai, bawang merah bawang putih. Bumbu-bumbu tersebut selanjutnya diblender hingga halus. Sementara itu, ikan pari asap dikukus untuk mengurangi efek kontaminasi silang mikroba akibat kondisi penyimpanan ikan asap selama distribusi dan penjualan. Setelah dikukus, ikan pari asap dikecilkan ukurannya menggunakan chopper agar menjadi ikan pari asap suwir.

Setelah bumbu halus dan ikan pari asap suwir telah siap, tahap selanjutnya adalah proses pemasakan sambal dengan cara menggoreng bahan-bahan tersebut menggunakan wajan anti lengket dengan tiga variasi cara pemasakan. Variasi cara pemasakan sambal ikan pari asap kemasan jar kaca pada penelitian ini adalah pemasakan kering, setengah kering dan kering dengan penambahan minyak goreng. Pada pemasakan kering, sambal ikan pari asap dimasak selama 90 menit hingga kering. Pada pemasakan setengah kering, sambal ikan pari asap dimasak selama 45 menit. Pada pemasakan kering dengan penambahan minyak setelah pemasakan, sambal ikan pari asap dimasak selama 90 menit hingga kering dan ditambahkan minyak goreng (kelapa sawit) setelah pemasakan.

Langkah terakhir proses pembuatan sambal ikan pari asap pada penelitian ini adalah pengemasan sambal dengan jar kaca. Jar kaca yang digunakan untuk mengemas 
produk disterilisasi terlebih dahulu sebelum digunakan. Sterilisasi jar kaca dilakukan dengan cara menempatkan jar kaca pada panci besar berisi air hangat dan merebusnya hingga air mendidih selama 10 menit (Fellows dan Axtell, 2002). Setelah disterilisasi, jar kaca dibiarkan kering sebelum digunakan untuk mengemas. Selanjutnya sambal ikan pari asap dimasukkan ke dalam jar kaca menggunakan metode hot filling dengan menyisakan headspace (jarak antara produk dengan penutup kemasan) dan kemudian jar kaca ditutup rapat. Selanjutnya dilakukan penyegelan jar kaca dengan menggunakan plastik seal yang direkatkan menggunakan heat gun.

\section{Pengamatan penurunan mutu sambal ikan pari asap}

Pengamatan penurunan mutu sambal ikan pari asap menggunakan metode Accelerated Shelf Life Test (ASLT) model Arrhenius. Sambal ikan pari asap disimpan pada tiga suhu penyimpanan yang berbeda yaitu suhu $35^{\circ} \mathrm{C}, 45^{\circ} \mathrm{C}$, dan $55^{\circ} \mathrm{C}$ (Kusnandar, 2008). Sampel diamati selama 48 jam penyimpanan dengan waktu pengamatan setiap 12 jam sekali yaitu pada jam ke-0, 12, 24, 36 dan 48 untuk mengetahui laju penurunan mutu sambal berdasarkan parameter sensoris aroma dengan metode uji pembanding jamak (Setyaningsih dkk, 2010) menggunakan 25 panelis terlatih, total asam tertitrasi (TAT) dengan metode titrasi (Utami, 2012), dan total plate count (TPC) dengan metode pour plate (AOAC, 1990). Selanjutnya data yang diperoleh dari hasil pengujian dirata-rata kemudian diolah menjadi plot Arrhenius sehingga dapat diketahui konstanta laju reaksi pada suhu yang lain.

\section{Pendugaan umur simpan}

Pendugaan umur simpan dihitung berdasarkan laju reaksi penurunan mutu yaitu orde 0 maupun orde 1. Persamaan Arrhenius yang digunakan adalah sebagai berikut:

$$
\begin{aligned}
& \text { Orde } 0: t=\frac{\left(Q_{0}-Q_{t}\right)}{\mathrm{k}} \\
& \text { Orde 1: } t=\frac{\ln \left(\frac{Q_{0}}{Q_{t}}\right)}{\mathrm{k}}
\end{aligned}
$$

Keterangan:

$\mathrm{t}$ = umur simpan

$\mathrm{Q}_{0}=$ nilai mutu awal

$\mathrm{Q}_{\mathrm{t}}=$ nilai batas kritis/batas mutu akhir

$\mathrm{k}=$ konstanta laju reaksi

\section{Rancangan Penelitian}

Perlakuan yang diberikan dalam penelitian ini adalah variasi pemasakan $(\mathrm{P})$ sambal yaitu pemasakan kering, setengah kering, dan penambahan minyak goreng setelah pemasakan. Sambal disimpan pada 3 suhu penyimpanan (T) untuk digunakan dalam metode Accelerated Shelf Life Test (ASLT). Umur simpan sambal ditentukan dengan menggunakan persamaan Arrhenius yang diolah menggunakan aplikasi microsoft excel. Data yang diperoleh kemudian diplotkan dalam grafik hubungan antara waktu (sumbu $x$ ) dengan rata-rata pada masing-masing suhu penyimpanan (sumbu y).

\section{HASIL DAN PEMBAHASAN}

\section{Penurunan Kualitas Sambal Ikan Pari Asap Kemasan Jar Kaca}

\section{Aroma}

Aroma adalah atribut yang keluar akibat adanya senyawa volatil yang mudah menguap dan dapat dirasakan oleh indra penciuman (Supit dkk, 2015). Jika aroma sudah diterima, maka penentuan penerimaan produk selanjutnya adalah berdasarkan cita rasa disamping teksturnya (Nursari dkk, 2016). Tabel 1 menunjukkan skor aroma sambal ikan pari asap kemasan jar kaca selama penyimpanan 48 jam yang dibandingkan dengan kontrol. Kontrol yang digunakan adalah sambal ikan pari asap kemasan jar kaca yang dimasak pada hari pengujian. 
Tabel 1 Kualitas Aroma Sambal Ikan Pari Asap Kemasan Jar Kaca dengan Variasi Cara Pemasakan

\begin{tabular}{|c|c|c|c|c|}
\hline \multirow{2}{*}{ Variasi Pemasakan } & \multirow{2}{*}{ Waktu (jam) } & \multicolumn{3}{|c|}{ Skor Aroma } \\
\hline & & $35\left({ }^{\circ} \mathrm{C}\right)$ & $45\left({ }^{\circ} \mathrm{C}\right)$ & $55\left({ }^{\circ} \mathrm{C}\right)$ \\
\hline \multirow{5}{*}{ Kering } & 0 & 3,72 & 3,72 & 3,72 \\
\hline & 12 & 4,00 & 4,04 & 4,12 \\
\hline & 24 & 4,24 & 4,52 & 4,72 \\
\hline & 36 & 4,64 & 4,72 & 4,92 \\
\hline & 48 & 4,96 & 5,36 & 5,60 \\
\hline \multirow{5}{*}{ Setengah Kering } & 0 & 3,92 & 3,92 & 3,92 \\
\hline & 12 & 3,96 & 4,04 & 4,12 \\
\hline & 24 & 4,40 & 4,68 & 4,84 \\
\hline & 36 & 5,08 & 5,32 & 5,68 \\
\hline & 48 & 5,44 & 5,76 & 5,80 \\
\hline \multirow{5}{*}{ Kering+minyak } & 0 & 3,84 & 3,84 & 3,84 \\
\hline & 12 & 3,92 & 3,96 & 4,08 \\
\hline & 24 & 4,36 & 4,44 & 4,76 \\
\hline & 36 & 4,40 & 4,72 & 5,00 \\
\hline & 48 & 4,96 & 5,08 & 5,52 \\
\hline
\end{tabular}

Keterangan skor sensoris aroma sambal ikan pari asap dibandingkan dengan kontrol:

1: sangat lebih baik, 2: lebih baik, 3: agak lebih baik, 4: sama, 5: agak lebih buruk, 6: lebih buruk, 7: sangat lebih buruk

Penolakan panelis pada sambal ikan pari asap kemasan jar kaca ditandai dengan skor aroma yang mencapai 5 atau lebih. Sambal yang dimasak kering mulai ditolak pada jam ke 48 pada suhu penyimpanan $45^{\circ} \mathrm{C}$ dan $55^{\circ} \mathrm{C}$. Sambal yang dimasak setengah kering ditolak pada jam ke-36 penyimpanan pada semua suhu penyimpanan. Pada suhu penyimpanan $45^{\circ} \mathrm{C}$ jam ke-48, sambal yang dimasak kering dan ditambah minyak ditolak, begitu juga pada suhu penyimpana $55^{\circ} \mathrm{C}$ jam ke-36 mulai ditolak. Penolakan panelis terhadap sambal tersebut terjadi akibat timbulnya aroma tidak sedap (busuk).

Aroma busuk yang timbul pada sambal selama penyimpanan disebabkan oleh aktivitas mikroba. Jumlah mikroba dalam sambal (Tabel 3) terus mengalami peningkatan selama penyimpanan, sehinga aktivitas mikroba pun semakin meningkat dan menyebabkan aroma busuk semakin tercium.

Aroma menyimpang yang timbul selama penyimpanan sambal ikan pari asap juga dapat disebabkan oleh reaksi oksidasi. Menurut Winarno (2008), reaksi oksidasi merupakan reaksi berantai pembentukan radikal yang melepaskan hidrogen dan menyebabkan kerusakan lemak serta menimbulkan bau dan rasa tengik yang disebut proses ketengikan. Ketaren (2005) dalam Hamida (2010) juga menambahkan bahwa hasil oksidasi lemak dalam pangan tidak hanya menghasilkan rasa dan bau yang tidak enak namun juga dapat menurunkan nilai gizi pangan.

\section{Total Asam Tertitrasi (TAT)}

Total asam tertitrasi (TAT) merupakan persentase asam dalam bahan yang ditentukan secara titrasi dengan basa standar. Total asam yang ada dalam bahan pangan mempengaruhi keawetan pangan untuk disimpan lebih lama (Sukandar dkk, 2014). Total asam tertitrasi pada bahan pangan terbentuk akibat pembentukan asam organik oleh aktivitas mikroorganisme dalam memecah karbohidrat, protein, dan zat-zat organik (Wulandari, 2001). Total asam tertitrasi berkaitan dengan kandungan asam organik berupa asam laktat, asam malat, dan asam asetat dalam pangan. Kandungan asam pada sambal ikan pari asap dapat berpengaruh terhadap rasa dan aroma sambal. 
Tabel 2 Total Asam Tertitrasi Sambal Ikan Pari Asap Kemasan Jar Kaca dengan Variasi Cara Pemasakan

\begin{tabular}{ccccc}
\hline \multirow{2}{*}{ Variasi Pemasakan } & Waktu (jam) & \multicolumn{3}{c}{ Total Asam Tertitrasi (\%) } \\
\cline { 2 - 5 } & 0 & $35\left({ }^{\circ} \mathrm{C}\right)$ & $45\left({ }^{\circ} \mathrm{C}\right)$ & $55\left({ }^{\circ} \mathrm{C}\right)$ \\
\hline \multirow{3}{*}{ Kering } & 12 & 0,47 & 0,47 & 0,47 \\
& 24 & 0,48 & 0,51 & 0,56 \\
& 36 & 0,59 & 0,61 & 0,63 \\
\multirow{3}{*}{ Setengah Kering } & 48 & 0,61 & 0,63 & 0,67 \\
& 0 & 0,71 & 0,75 & 0,78 \\
\hline \multirow{3}{*}{ Kering+minyak } & 12 & 0,49 & 0,49 & 0,49 \\
& 24 & 0,51 & 0,53 & 0,56 \\
& 36 & 0,61 & 0,64 & 0,65 \\
& 48 & 0,63 & 0,66 & 0,68 \\
& 0 & 0,76 & 0,78 & 0,80 \\
\hline & 12 & 0,49 & 0,49 & 0,49 \\
& 36 & 0,51 & 0,52 & 0,52 \\
& 48 & 0,59 & 0,61 & 0,63 \\
& 0,60 & 0,62 & 0,66 \\
\hline
\end{tabular}

Berdasarkan Tabel 2, nilai total asam tertitrasi sambal selama penyimpanan terus meningkat. Kenaikan total asam pada sambal seiring dengan peningkatan jumlah mikrobia (Tabel 3), yang mana aktivitas mikrobia penghasil asam semakin meningkat.

Selama penyimpanan, total asam yang terbentuk pada sambal ikan pari asap kemasan jar kaca belum melebihi batas standar, yaitu $0,5 \%$ hingga 2\% (Badan Standarisasi Nasional, 2009), sedangkan jumlah mikroba (Tabel 3) telah melebihi standar. Diduga mikrobia yang terdapat dalam sambal ikan pari asap didominasi bakteri pendegradasi asam amino dibandingkan bakteri penghasil asam organik. Aktivitas bakteri penghasil asam dalam memproduksi asam organik biasanya terjadi pada pangan dengan kandungan karbohidrat tinggi (Weiser, 1962), padahal ikan pari lebih kaya protein dibanding karbohidrat . Menurut Irianto dan Giyatmi (2009), ikan pada umumnya mengandung karbohidrat berupa glikogen yang tersimpan di jaringan otot dalam jumlah yang sangat rendah yaitu sekitar $0,1-1 \%$.

\section{Total Plate Count (TPC)}

Jumlah mikroba yang tumbuh selama penyimpanan dalam penelitian ini dihitung dengan parameter total plate count (TPC).
Menurut Fardiaz (1993), jumlah koloni yang tumbuh merupakan jumlah seluruh mikrobia yang terdapat dalam bahan pangan seperti bakteri, kapang dan khamir. Kualitas bahan pangan dianggap rendah jika nilai TPC tinggi, karena dapat membahayakan jika dikonsumsi, terkait keamanan produk pangan.

Total plate count (TPC) sambal ikan pari asap kemasan jar kaca (Tabel 3) terus meningkat pada tiap suhu penyimpanan pada semua variasi cara pemasakan selama penyimpanan. Hal tersebut terutama diduga disebabkan oleh bakteri-bakteri yang tumbuh (recovery) selama penyimpanan, dengan didukung suhu optimal untuk pertumbuhannya selama penyimpanan. Mikroba mesofil tumbuh maksimum pada suhu $40-47^{\circ} \mathrm{C}$ dan optimum pada suhu 30$40^{\circ} \mathrm{C}$ (Sopandi dan Wardah, 2014). Selain itu, menurut Sobhi et al, (2012) produk sambal yang menggunakan bahan dasar terasi secara alami mengandung bakteri genus Bacillus, Clostridium, Enterobacter, Escherichia, Micrococcus, Proteus, Streptococcus, Acetobacter, Pediococcus, Lactobacillus, Sarcina, dan Staphylococcus, dan menurut Ekawati dkk (2005) ikan pari asap mengandung bakteri Staphylocuccus aureus. 
Tabel 3 Total Plate Count Sambal Ikan Pari Asap Kemasan Jar Kaca dengan Variasi Cara Pemasakan

\begin{tabular}{ccccc}
\hline \multirow{2}{*}{ Variasi Pemasakan } & \multirow{2}{*}{ Waktu (jam) } & \multicolumn{3}{c}{ Total Mikroba (CFU/gram) } \\
\cline { 2 - 5 } & 0 & $35\left({ }^{\circ} \mathrm{C}\right)$ & $45\left({ }^{\circ} \mathrm{C}\right)$ & $55\left({ }^{\circ} \mathrm{C}\right)$ \\
\hline \multirow{3}{*}{ Kering } & 12 & $6,90 \times 10^{2}$ & $7,70 \times 10^{3}$ & $7,70 \times 10^{2}$ \\
& 24 & $1,84 \times 10^{4}$ & $8,25 \times 10^{3}$ & $8,63 \times 10^{3}$ \\
& 36 & $1,27 \times 10^{5}$ & $2,39 \times 10^{4}$ & $2,40 \times 10^{4}$ \\
& 48 & $1,47 \times 10^{5}$ & $1,85 \times 10^{5}$ & $2,08 \times 10^{5}$ \\
\multirow{5}{*}{ Setengah Kering } & 0 & $8,48 \times 10^{2}$ & $8,48 \times 10^{2}$ & $2,16 \times 10^{5}$ \\
& 12 & $8,75 \times 10^{3}$ & $9,25 \times 10^{3}$ & $8,48 \times 10^{2}$ \\
& 24 & $2,02 \times 10^{4}$ & $2,21 \times 10^{4}$ & $2,27 \times 10^{4}$ \\
& 36 & $2,06 \times 10^{5}$ & $2,27 \times 10^{5}$ & $2,51 \times 10^{5}$ \\
Kering+minyak & 48 & $2,30 \times 10^{5}$ & $2,40 \times 10^{5}$ & $2,58 \times 10^{5}$ \\
& 0 & $7,68 \times 10^{2}$ & $7,68 \times 10^{2}$ & $7,68 \times 10^{2}$ \\
& 12 & $7,53 \times 10^{3}$ & $8,70 \times 10^{3}$ & $9,10 \times 10^{3}$ \\
& 24 & $1,76 \times 10^{4}$ & $2,48 \times 10^{4}$ & $2,55 \times 10^{4}$ \\
& 36 & $1,00 \times 10^{5}$ & $1,53 \times 10^{5}$ & $2,07 \times 10^{5}$ \\
& 48 & $1,35 \times 10^{5}$ & $1,87 \times 10^{5}$ & $2,68 \times 10^{5}$ \\
\hline
\end{tabular}

Selama penyimpanan, jumlah mikrobia melebihi batas maksimal menurut SNI 014865.1-1998 yaitu $10^{4} \mathrm{CFU} / \mathrm{gram}$ (Badan Standarisasi Nasional, 1998). Pada suhu penyimpana $35^{\circ} \mathrm{C}$ dan $45^{\circ} \mathrm{C}$, nilai $\mathrm{TPC}$ sambal pada semua variasi pemasakan melebihi batas SNI pada jam ke-24 penyimpanan. Pada suhu penyimpanan $55^{\circ} \mathrm{C}$, nilai TPC sambal yang dimasak kering dan kering ditambah minyak melebihi batas SNI pada jam ke-24, sedangkan sambal setengah kering sudah tidak memenuhi SNI pada jam ke-12.

Peningkatan jumlah mikroba tertinggi selama penyimpanan terdapat pada sambal ikan pari asap yang dimasak setengah kering, yang mana kadar airnya paling tinggi yaitu sekitar 50,14\% dibandingkan variasi pemasakan lainnya. Kadar air sambal yang dimasak kering sebesar $34,97 \%$ dan sambal dengan variasi masak kering ditambah minyak memiliki kadar air $15,85 \%$. Air bebas dalam produk pangan diperlukan mikroba untuk transpor nutrisi, melaksanakan reaksi enzimatis, pengeluaran material limbah dan sintesis komponen seluler dan mengambil bagian reaksi biokimia yang lain seperti hidrolisis polimer menjadi monomer misalnya protein menjadi asam amino (Sopandi dan Wardah, 2014).

Sambal ikan pari asap dengan variasi pemasakan kering dengan penambahan minyak goreng memiliki nilai TPC yang paling rendah dibandingkan variasi pemasakan yang lain. Hal tersebut menunjukkan bahwa penambahan minyak goreng setelah pemasakan mempunyai pengaruh terhadap aktivitas mikroba pada sambal. Minyak goreng kelapa sawit mengandung asam lemak oleat (30-40\%), asam miristat $(1,1-2,5 \%)$, asam palmitat (40$46 \%$ ), asam stearat $(3,6-4,7)$ dan asam linoleat (7-11\%) (Pasaribu, 2004). Pada penelitian Kusmiyati (2007), ssam lemak metil heksadekanoat (asam palmitat) dari mikroalga Porphyridium cruentum merupakan senyawa anti bakteri. Selain itu, pada penelitian Muthezilan et al (2012), kandungan asam lemak oleat dari Solanum torvum SW dapat menghambat pertumbuhan bakteri Escherichia coli Micrococcus sp, Enterococcus faecalis, Staphylococcus aureus, Streptococcus sp. and Bacillus s, sehingga kandungan asam lemak palmitat dan asam lemak oleat dalam minyak goreng yang ditambahkan pada sambal setelah pemasakan dimungkinkan pula dapat menghambat pertumbuhan bakteri.

\section{Kinetika Penurunan Kualitas}

Selama penyimpanan, sambal ikan pari asap kemasan jar kaca mengalami penurunan kualitas akibat aktivitas mikroba yang menyebabkan penurunan kualitas aroma dan TAT. Data penurunan kualitas aroma dan TAT digunakan untuk mengetahui kinetika penurunan kualitas melalui pemilihan orde reaksi. Orde reaksi penurunan kualitas pada 
makanan dijelaskan melalui dua orde reaksi yaitu orde reaksi nol (penurunan kualitas mengikuti garis linier) dan orde reaksi satu (penurunan kualitas mengikuti garis eksponensial). Pangan dengan ordo reaksi nol dicirikan dengan adanya penurunan kualitas yang bersifat lurus, umumnya karakteristik tersebut dimiliki oleh pangan beku dan produk yang rentan terhadap pencoklatan non-enzimatis. Pangan dengan ordo reaksi satu dicirikan dengan penurunan kualitas yang sifatnya logaritmik, yaitu penurunan yang semakin rendah seiring dengan lama penyimpanan, umumnya karakteristik tersebut dimiliki oleh pangan yang rentan terhadap kehilangan vitamin, inaktivasi mikroba, kerusakan warna oksidatif, serta kerusakan tekstur karena suhu (Pitasari dkk, 2015). Pemilihan orde reaksi dilakukan dengan membandingkan koefisien determinasi $\left(\mathrm{R}^{2}\right)$ pada persamaan regresi linear reaksi orde nol dan orde satu pada masing-masing suhu penyimpanan. Orde reaksi dengan koefisien determinasi $\left(\mathrm{R}^{2}\right)$ lebih besar atau lebih mendekati 1 dipilih menjadi orde reaksi penurunan mutu produk pada suhu tersebut. Selanjutnya data yang diperoleh diolah lebih lanjut untuk mengetahui umur simpan produk dengan menggunakan persamaan Arrhenius.

\section{Penurunan Kualitas Aroma}

Orde reaksi penurunan kualitas aroma sambal ikan pari asap kemasan jar kaca dilakukan dengan memproyeksikan waktu (x) versus skor aroma (y) menjadi grafik orde 0 dan orde 1 sehingga didapatkan persamaan regresi linier dan koefisien determinasi $\left(\mathrm{R}^{2}\right)$ pada Tabel 4.

Tabel 4 menunjukkan nilai $\mathrm{R}^{2}$ orde reaksi 1 dominan lebih besar jika dibandingkan dengan $\mathrm{R}^{2}$ pada orde 0 . Menurut Hariyadi (2008), aroma yang timbul sebagai akibat produksi off flavor dari aktivitas mikroba dijelaskan dengan orde 1 . Sehingga penurunan kualitas aroma mengikuti garis eksponensial. Selanjutnya, nilai slope persamaan regresi linier orde 1 yang merupakan nilai konstanta laju reaksi (k) digunakan untuk menentukan persamaan Arrhenius dengan cara memplotkan nilai 1/T untuk sumbu $\mathrm{x}$ dan ln k untuk sumbu y, yang mana $\mathrm{T}$ merupakan suhu penyimpanan yang dijadikan satuan Kelvin. Grafik persamaan Arrhenius pada penurunan kualitas aroma sambal ikan pari asap kemasan jar kaca dapat dilihat pada Gambar 1.

Tabel 4 Persamaan Regresi Linier Grafik Penurunan Kualitas Aroma dan Koefisien Determinasinya $\left(\mathrm{R}^{2}\right)$

\begin{tabular}{cccccr}
\hline \multirow{2}{*}{$\begin{array}{l}\text { Variasi } \\
\text { Masak }\end{array}$} & \multirow{2}{*}{ Suhu } & \multicolumn{2}{c}{ Persamaan Regresi } & \multicolumn{2}{c}{$\mathrm{R}^{2}$} \\
\cline { 3 - 6 } Orde 0 & \multicolumn{1}{c}{ Orde 1} & Orde 0 & Orde 1 \\
\hline \multirow{2}{*}{ Kering } & 35 & $\mathrm{y}=0,026 \mathrm{x}+3,688$ & $\mathrm{y}=0,006 \mathrm{x}+1,3114$ & 0,9928 & 0,9965 \\
& 45 & $\mathrm{y}=0,033 \mathrm{x}+3,68$ & $\mathrm{y}=0,0074 \mathrm{x}+1,3126$ & 0,9774 & 0,9846 \\
& 55 & $\mathrm{y}=0,038 \mathrm{x}+3,704$ & $\mathrm{y}=0,0083 \mathrm{x}+1,3204$ & 0,9807 & 0,9823 \\
\hline \multirow{2}{*}{ Setengah } & 35 & $\mathrm{y}=0,0347 \mathrm{x}+3,728$ & $\mathrm{y}=0,0075 \mathrm{x}+1,3784$ & 0,9405 & 0,946 \\
Kering & 45 & $\mathrm{y}=0,0413 \mathrm{x}+3,752$ & $\mathrm{y}=0,0087 \mathrm{x}+1,3366$ & 0,9675 & 0,9702 \\
& 55 & $\mathrm{y}=0,0443 \mathrm{x}+3,808$ & $\mathrm{y}=0,0092 \mathrm{x}+1,3498$ & 0,9476 & 0,9492 \\
\hline \multirow{2}{*}{ Kering+ } & 35 & $\mathrm{y}=0,0227 \mathrm{x}+3,752$ & $\mathrm{y}=0,0052 \mathrm{x}+1,3279$ & 0,9189 & 0,9297 \\
Minyak & 45 & $\mathrm{y}=0,027 \mathrm{x}+3,76$ & $\mathrm{y}=0,0061 \mathrm{x}+1,3308$ & 0,9781 & 0,9788 \\
& 55 & $\mathrm{y}=0,0357 \mathrm{x}+3,808$ & $\mathrm{y}=0,0077 \mathrm{x}+1,3401$ & 0,9785 & 0,977 \\
\hline
\end{tabular}



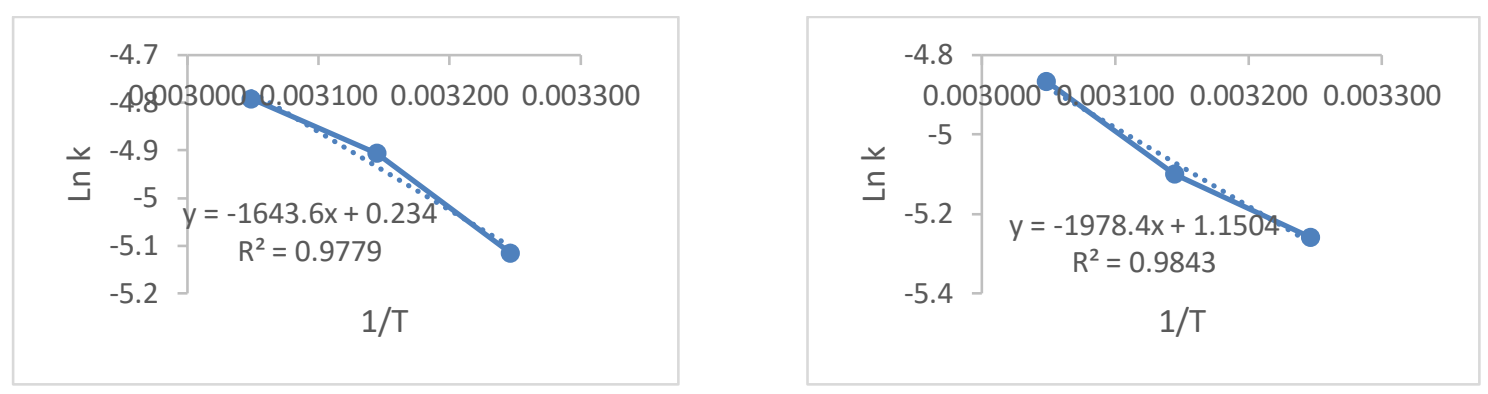

(a)

(b)

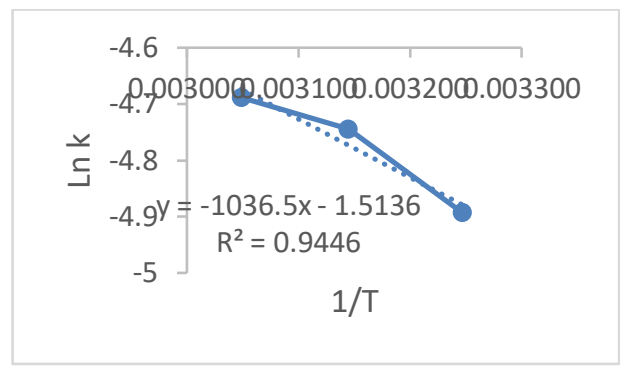

(c)

Gambar 1 Grafik Persamaan Arrhenius Penurunan Kualitas Aroma Sambal Ikan Pari Asap Kemasan Jar Kaca (a) Masak Kering, (b) Masak Setengah Kering, (c) Masak Kering+Minyak

Penurunan Kualitas Total Asam Tertitrasi (TAT)

Orde reaksi penurunan kualitas TAT sambal ikan pari asap kemasan jar kaca dilakukan dengan memproyeksikan waktu (x) versus skor aroma (y) menjadi grafik orde 0 dan orde 1 sehingga didapatkan persamaan regresi linier dan koefisien determinasi $\left(\mathrm{R}^{2}\right)$ pada Tabel 5.

Seperti halnya pada Tabel 4, berdasarkan Tabel 5, nilai $\mathrm{k}$ reaksi orde 1 digunakan untuk menentukan persamaan Arrhenius. Total asam yang terbentuk akibat dari aktivitas mikroba menurut Hariyadi (2008) dijelaskan dengan orde 1. Grafik persamaan Arrhenius total asam tertitrasi sambal ikan pari asap kemasan jar kaca dapat dilihat pada Gambar 2.

Berdasarkan Gambar 2 didapatkan persamaan Arrhenius TAT y $=-533,28 \mathrm{x}-$ 2,9758 pada variasi cara masak kering, pada variasi masak setengah kering didapatkan persamaan $\mathrm{y}=-270,7 \mathrm{x}-3,819$ dan pada variasi masak kering dengan penambahan minyak goreng didapatkan persamaan $\mathrm{y}=$ 699,38x - 2,6375. Keseluruhan persamaan yang diperoleh digunakan untuk mengetahui nilai $\mathrm{k}$ maupun nilai Ea yang dapat dilihat pada Tabel 7. Nilai $\mathrm{k}$ maupun nilai Ea tersebut digunakan untuk menduga umur simpan sambal.

Tabel 5 Persamaan Regresi Linier Grafik Penurunan Kualitas Total Asam Tertitrasi dan Koefisien Determinasinya $\left(\mathrm{R}^{2}\right)$

\begin{tabular}{|c|c|c|c|c|c|}
\hline \multirow{2}{*}{$\begin{array}{l}\text { Variasi } \\
\text { Masak }\end{array}$} & \multirow{2}{*}{ Suhu } & \multicolumn{2}{|c|}{ Persamaan Regresi } & \multicolumn{2}{|c|}{$\mathrm{R}^{2}$} \\
\hline & & Orde 0 & Orde 1 & Orde 0 & Orde 1 \\
\hline \multirow{3}{*}{ Kering } & 35 & $y=0,0052 x+0,4479$ & $y=0,009 x-0,788$ & 0,947 & 0,9517 \\
\hline & 45 & $y=0,0057 x+0,457$ & $y=0,0096 x-0,7662$ & 0,9553 & 0,9656 \\
\hline & 55 & $\mathrm{y}=0,0061 \mathrm{x}+0,4738$ & $\mathrm{y}=0,01 \mathrm{x}-0,7325$ & 0,9754 & 0,9702 \\
\hline \multirow{3}{*}{$\begin{array}{c}\text { Setengah } \\
\text { Kering }\end{array}$} & 35 & $y=0,0055 x+0,4662$ & $y=0,0091 x-0,7455$ & 0,9236 & 0,9384 \\
\hline & 45 & $y=0,0058 x+0,4784$ & $y=0,0094 x-0,7219$ & 0,9554 & 0,9606 \\
\hline & 55 & $y=0,0061 x+0,4876$ & $y=0,0096 x-0,7029$ & 0,9696 & 0,9742 \\
\hline \multirow{3}{*}{$\begin{array}{l}\text { Kering+ } \\
\text { Minyak }\end{array}$} & 35 & $y=0,0043 x+0,4738$ & $y=0,0074 x-0,7362$ & 0,9407 & 0,9497 \\
\hline & 45 & $y=0,0046 x+0,4769$ & $y=0,0079 x-0,7282$ & 0,9585 & 0,9708 \\
\hline & 55 & $y=0,0052 x+0,4876$ & $y=0,0085 x-0,7072$ & 0,9851 & 0,9838 \\
\hline
\end{tabular}




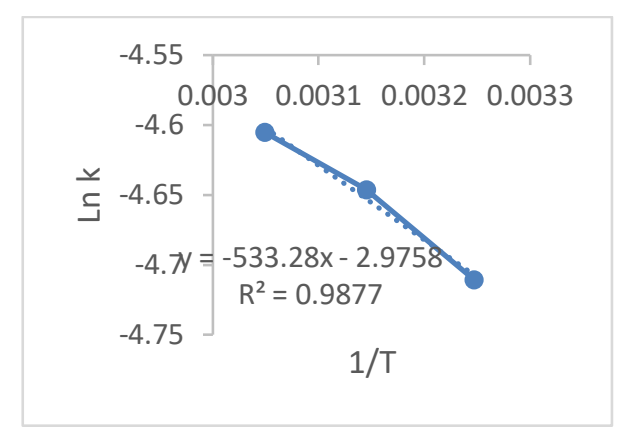

(a)

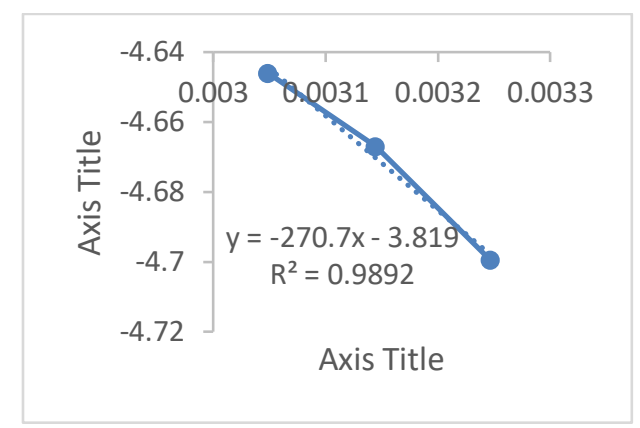

(b)

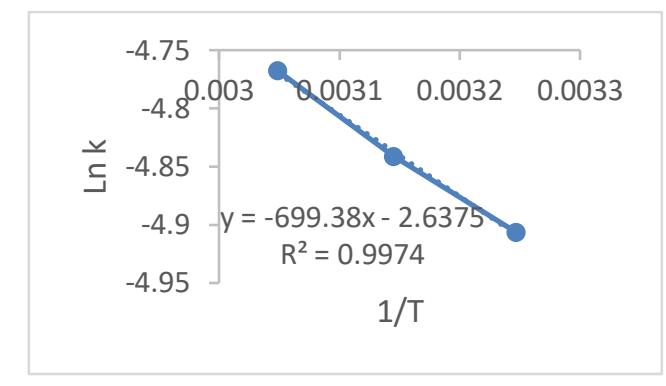

(c)

Gambar 2 Grafik Persamaan Arrhenius Penurunan Kualitas Total Asam Tertitrasi Sambal Ikan Pari Asap Kemasan Jar Kaca (a) Masak Kering, (b) Masak Setengah Kering, (c) Masak Kering+Minyak

\section{Pendugaan Umur Simpan}

Metode ASLT model Arrhenius membutuhkan data mutu awal produk yang diperoleh dari nilai kualitas parameter pada jam ke-0 penyimpanan (kualitas awal) serta nilai batas kritis kualitas produk yang menjadi batas tolak produk oleh konsumen. Kualitas awal dan batas kritis mutu sambal ikan pari asap dapat dilihat pada Tabel 6.

Aroma dan TAT sambal ikan pari asap kemasan jar kaca dengan variasi cara pemasakan pada jam ke-0 penyimpanan masih normal. Pendugaan umur simpan ditentukan dengan mengamati penurunan kualitas sampai batas kritis. Menurut Kusnandar (2008), kriteria pemilihan parameter mutu kritis untuk penentuan umur simpan yaitu :

1. Parameter yang paling cepat mengalami penurunan mutu selama penyimpanan. Hal ini ditunjukkan dengan nilai koefisien $\mathrm{k}$ mutlak dan/atau memiliki nilai koefisien korelasi $\left(\mathrm{R}^{2}\right)$ yang paling besar.

2. Parameter yang paling sensitif terhadap perubahan suhu. Hal ini ditunjukkan dengan slope pada model Arrhenius dan nilai Ea yang paling rendah.

3. Apabila terdapat lebih dari satu parameter mutu yang memenuhi kriteria 1 dan 2 , maka dipilih umur simpan yang paling pendek.

Pada Tabel 7 dapat dilihat nilai koefisien determinasi $\left(\mathrm{R}^{2}\right)$, nilai energi aktivasi (Ea), persamaan regresi dan nilai konstanta laju reaksi (k) yang digunakan dalam menghitung umur simpan. Nilai Ea diperoleh dari perkalian slope dengan konstanta gas ( $\mathrm{R}$ ) dengan nilai $\mathrm{R}$ sebesar $8,314 \mathrm{~J} / \mathrm{g}$ mol K. Nilai $\mathrm{k}$ diperoleh dari persamaan Arrhenius yaitu:

$$
\ln \mathrm{k}=\ln \mathrm{k}_{0}-\left(\frac{\mathrm{Ea}}{\mathrm{R}}\right)\left(\frac{1}{\mathrm{~T}}\right) .
$$

Keterangan:

$\mathrm{K}=$ konstanta laju reaksi

$\mathrm{k}_{0} \quad=$ faktor frekuensi reaksi

$\mathrm{Ea}=$ energi aktivasi

$\mathrm{R}=$ konstanta gas $(8,314 \mathrm{~J} / \mathrm{g}$ mol K$)$

$\mathrm{T}$ = suhu yang dinyatakan dalam derajat Kelvin (K) 
Tabel 6 Nilai Kualitas Awal dan Batas Kritis Parameter pada Sambal Ikan Pari Asap Kemasan Jar Kaca dengan Variasi Cara Pemasakan

\begin{tabular}{lcccc}
\hline \multirow{2}{*}{ Variasi Pemasakan } & \multicolumn{4}{c}{ Parameter } \\
\cline { 2 - 5 } & Mutu Awal & Batas Kritis Mutu & Mutu Awal & Batas Kritis Mutu* \\
\cline { 2 - 5 } & 3,72 & maks 5 & 0,47 & maks 2 \\
Kering & 3,92 & maks 5 & 0,5 & maks 2 \\
Setengah Kering & 3,84 & maks 5 & 0,49 & maks 2 \\
Kering+ Minyak & & & &
\end{tabular}

Keterangan :

* berdasarkan SNI 01-2981:2009

** 1: sangat lebih baik, 2: lebih baik, 3: agak lebih baik, 4: sama, 5: agak lebih buruk, 6: lebih buruk, 7: sangat lebih buruk

Tabel 7 Persamaan Arrhenius dan Energi Aktivasi (Ea) Setiap Parameter Sambal Ikan Pari Asap Kemasan Jar Kaca dengan Variasi Cara Pemasakan

\begin{tabular}{cccccc}
\hline $\begin{array}{c}\text { Variasi } \\
\text { Pemasakan }\end{array}$ & Parameter & Persamaan & $\mathrm{R}^{2}$ & Slope & $\begin{array}{c}\text { Ea } \\
(\mathrm{J} / \mathrm{g} \\
\mathrm{mol} . \mathrm{K})\end{array}$ \\
\hline \multirow{2}{*}{ Kering } & Aroma & $\mathrm{y}=-1643,6 \mathrm{x}+0,234$ & 0,9779 & 1643,6 & 13664,89 \\
\cline { 2 - 6 } & TAT & $\mathrm{y}=-533,28 \mathrm{x}-2,9758$ & 0,9877 & 533,28 & 4486,49 \\
\hline \multirow{2}{*}{ Setengah Kering } & Aroma & $\mathrm{y}=-1036,5 \mathrm{x}-1,5136$ & 0,9446 & 1036,5 & 8617,46 \\
\hline \multirow{2}{*}{ Kering+Minyak } & TAT & $\mathrm{y}=-270,7 \mathrm{x}-3,819$ & 0,9892 & 270,7 & 2250,60 \\
\cline { 2 - 6 } & Aroma & $\mathrm{y}=-1978,4 \mathrm{x}+1,1504$ & 0,9843 & 1978,4 & 16448,42 \\
\hline
\end{tabular}

Tabel 8 Pendugaan Umur Simpan Sambal Ikan Pari Asap Kemasan Jar Kaca dengan Variasi Pemasakan pada Suhu Ruang $\left(30^{\circ} \mathrm{C}\right)$

\begin{tabular}{ccc}
\hline Variasi Pemasakan & $\mathrm{k}$ & Umur Simpan (jam) \\
\hline Kering & 0,00878 & 165,95 \\
Setengah Kering & 0,00898 & 155,04 \\
Kering+Minyak & 0,00711 & 197,96 \\
\hline
\end{tabular}

Pendugaan umur simpan sambal ikan pari asap kemasan jar kaca dengan variasi cara pemasakan dilakukan pada suhu ruang $\left(30^{\circ} \mathrm{C}\right)$, yang dapat dilihat pada Tabel 8 . Persamaan model Arrhenius yang digunakan untuk menduga umur simpan adalah sebagai berikut:

Keterangan:

$$
t=\frac{\ln \left(\frac{Q_{0}}{Q_{t}}\right)}{\mathrm{k}}
$$

$\mathrm{t} \quad=$ umur simpan

$\mathrm{Q}_{0}=$ nilai mutu awal

$\mathrm{Q}_{\mathrm{t}}=$ nilai batas kritis/batas mutu akhir

$\mathrm{k} \quad=$ konstanta laju reaksi

Pendugaan umur simpan sambal ikan pari asap ditentukan berdasarkan parameter total asam tertitrasi (TAT), karena memiliki nilai $\mathrm{Ea}$ dan slope terendah serta nilai $\mathrm{R}^{2}$ paling tinggi. Berdasarkan Tabel 8, diketahui umur simpan sambal ikan pari asap kemasan jar kaca dengan variasi masak kering adalah 165,95 jam, pada variasi masak setengah kering memiliki umur simpan 155,04, dan pada variasi masak kering dengan penambahan minyak memiliki umur simpan197,96 jam pada suhu ruang $\left(30^{\circ} \mathrm{C}\right)$.

Umur simpan terlama dari keseluruhan variasi cara pemasakan adalah variasi masak kering dengan penambahan minyak goreng. Penambahan minyak setelah pemasakan menghambat pertumbuhan mikroba penghasil asam. Minyak yang ditambahkan pada sambal adalah minyak kelapa sawit yang mengandung asam lemak oleat (30$40 \%)$, asam miristat $(1,1-2,5 \%)$, asam palmitat $(40-46 \%)$, asam stearat $(3,6-4,7)$ dan asam linoleat (7-11\%) (Pasaribu, 2004). Asam lemak metil heksadekanoat (asam 
palmitat) dari mikroalga Porphyridium cruentum merupakan senyawa anti bakteri (Kusmiyati, 2007). Selain itu, pada penelitian Muthezilan et al (2012), asam oleat dari Solanum torvum SW dapat menghambat pertumbuhan bakteri Escherichia coli Micrococcus sp, Enterococcus faecalis, Staphylococcus aureus, Streptococcus sp. and Bacillus s,. Sehingga diduga asam palmitat dan asam oleat dalam minyak goreng yang ditambahkan pada sambal dapat pula menghambat pertumbuhan bakteri.

\section{KESIMPULAN}

Sambal ikan pari asap kemasan jar kaca dengan variasi cara pemasakan kering dengan penambahan minyak goreng kualitas aromanya paling baik ( mendekati aroma sambal segar) pada hari dan suhu yang sama selama penyimpanan, sebelum mengalami penolakan. Total asam tertitrasinya juga paling baik (rendah) dibandingkan sambal dengan cara pemsakan kering dan setengah kering. Namun demikian, total plate count (TPC) sambal ikan pari asap kemasan jar kaca dengan variasi cara pemasakan kering dengan penambahan minyak goreng relatif tidak berbeda dengan sambal yang lain. Sambal terbaik adalah sambal dengan pemasakan kering ditambah minyak dengan umur simpan 197,96 jam.

\section{DAFTAR PUSTAKA}

Arpah, M. dan Syarief, R. 2000. Evaluasi Model-model Pendugan Umur Simpan Pangan dari Difusi Hukum Fick Undireksional. Buletin Teknologi dan Industri Pangan.

Dewi, E.N., Ibrahim, R., dan Yuaniva, N. 2011. Daya Simpan Ikan Nila Merah (Oreochromis niloticus Trewavas) yang Diproses dengan Metoda Penggorengan Berbeda. Jurnal Saintek Perikanan, Vol. 6(1):6-12

Ekawati, P., Martini, dan Yuliawati, S. 2005. Kontaminan Staphylococcus aureus Pada Ikan Asap di Tingkat Produsen dan Penjual di Semarang. Jurnal
Kesehatan Masyarakat Indonesia, Vol 2(2)

Fardiaz, S. 1993. Analisis Mikrobiologi Pangan. RajaGrafindo Persada. Jakarta.

Fellows, P.J. dan Axtell, B.L. 2002. Packaging Foods in Glass. Practical Action Publishing ILO. UK

Hamida, E. 2010. Oksidasi Lemak Dendeng Kering Oven Selama Penyimpanan yang Diuji Setelah Mengalami Penggorengan. Skripsi. IPB. Bogor.

Hariyadi, P. 2008. Prinsip-prinsip Penentuan dan Pendugaan Masa Kadaluarsa Produk Pangan. Institut Pertanian Bogor. Bogor.

Herawati, H. 2008. Penentuan Umur Simpan pada Produk Pangan. Jurnal Litbang Pertanian, Vol. 27(4): 124-130.

Irianto, H.E., dan Giyatmi, S. 2009. Teknologi Pengolahan Hasil Perikanan. Penerbit Universitas Terbuka. Jakarta.

Koswara, S. 2009. Teknologi Pengolahan Sayuran dan Buah-Buahan (Teori dan Praktek. Ebookpangan.com

Kusmiyati, N.W.S.A. 2007. Uji Aktivitas Senyawa Antibakteri dari Mikroalga Porphyriduim cruentum. Biodiversitas, Vol. 8(1):48:53.

Kusnandar, F. 2008. Desain Percobaan Dalam Penetapan Umur Simpan Produk Pangan dengan Metode ASLT. Institut Pertanian Bogor. Bogor.

Muthezhilan, R., Yogananth, N., Priyanka, dan Hussain, A.J. 2012. Fatty Acid Composition and Antimicrobial Activity of Solanum torvum SW. Journal of Modern Biotechnology, Vol. 1(2) pp 75-78

Novianti, A., Achyadi, H.S., dan Garnida, Y. 2016. Pengaruh Jenis dan Konsentrasi Bahan Penstabil Terhadap Karakteristik Sambal "Goang" Instan. Skripsi. Universitas Pasundan. Bandung.

Nursari, Karimuna, L., dan Tamrin. 2016. Pengaruh $\mathrm{pH}$ dan Suhu Pasteurisasi Terhadap Karakteristik Kimia, 
Organoleptik dan Daya Simpan Sambal. Jurnal Sains dan Teknologi Pangan, Vol. 1(2) pp 151-158.

Pasaribu, N. 2004. Minyak Buah Kelapa Sawit. Repository USU. Sumatera Utara.

Setyaningsih, D., Apriyantono, A., dan Sari M.P. 2010. Analisis Sensori Untuk Industri Pangan dan Agro. IPB Press. Bogor.

Shin, J. and Seike, S.E.M. 2014. Food Processing: Principle and Applications, Second Edition. John Wiley and Sons Publishing. USA.

Sobhi, B., Noranizan, M., Karim, S., Rahman, R.A., Bakar J., dan Ghazali, Z. 2012. Microbial and Quality Attributes Of Thermally Processed Chili Shrimp Paste. International Food Research Journal, Vol. 19(4): 1705-1712

Sopandi, T. dan Wardah. 2014. Mikrobiologi Pangan. Penerbit Andi. Yogyakarta.

Sukandar, D., Muawanah, A., Amelia E.R., dan Anggraeni, F.N. 2014. Aktivvitas Antioksidan dan Mutu Sensori Formulasi Minuman Fungsional SawoKayu Manis. Jurnal Kimia Valensi, Vol. 4(2):80-89

Sumaryanto, H., Pratama, R.I., dan Santoso, J. 2012. Karakteristik Kimia dan Sensori Ikan Pe. Seminar Nasional IX Hasil Perikanan dan Kelautan. IPB. Bogor.

Supit, J.W., Langi, T.M., dan Ludong, M.M. 2015. Analisis Sifat Fisikokimia dan Organoleptik Sambal "Cahero". Sripsi. Universitas Sam Ratulangi. Manado.

Utami, D.A. 2012. Studi Pengolahan dan Lama Penyimpanan Sambel Ulek Berbahan Dasar Cabe Merah, Cabe Keriting dan Cabe Rawit yang Difermentasi. Skripsi. Universitas Hasanuddin Makassar.

Wahyuningsih, I., Effendi, U., dan Hidayat, A. 2012. Analisis Kelayakan Usaha Produksi Sambal Petis Ikan Tuna Siap Saji (Studi Kasus Di UD. Madu Prima
Pamekasan Madura). Universitas Brawijaya. Malang.

Weiser, H.H. 1962. Practical Food Microbiology And Technology. AVI Publishing.

Winarno, F.G. 2008. Kimia Pangan dan Gizi. Brio Press. Bogor.

Wulandari. D. 2001. Penentuan Umur Simpan Saus Paprika (Capsicum annum var. Grossum) dari Bahan Baku Paprika Sisa Grading. IPB. Bogor. 